\title{
Hydrolysis of Red Beet Bagasse and Modeling of Hydrolysates for Bioethanol Production*
}

\author{
Donaji Jiménez-Islas ${ }^{\mathrm{a}}$ - Juan Manuel Rivera-Ríos ${ }^{\mathrm{b}}$ - Josué Addiel Venegas \\ Sánchez ${ }^{c}$ Jorge Noel Gracida Rodríguez ${ }^{\mathrm{d}}$
}

\begin{abstract}
Red beets in Mexico are used in the colorants industry, but their juice bagasse (RBB) can be carbohydrates for ethanol production. The present study aims to the pretreatment of bagasse of red beet using acid $\left(\mathrm{H}_{2} \mathrm{SO}_{4}\right)$ and alkali $(\mathrm{NaOH})$ to improve the availability of sugars. Also, describe quantitatively in the hydrolysates the microbial growth, substrate consumption, and ethanol production with simulation using data kinetics of red beet and logistic, Pirt, and Luedeking-Piret equations. Experiments with $\mathrm{H}_{2} \mathrm{SO}_{4}$ at sterilization conditions resulted in lower phenolic formation and increased hydrolysis to $32 \%$. Logistic, Pirt, and Luedeking-Piret equations were used to quantitatively describe the hydrolysates the microbial growth, substrate consumption, and ethanol production, respectively. In the alkali treatment, a significant mean difference was found $(p<0.05)$ in substrate mass and reaction time. The maximum yield of $38 \mathrm{~g} / \mathrm{L}$ of total sugars at $72 \mathrm{~h}$ of reaction was obtained from $6 \mathrm{~g}$ RBB and $\mathrm{H}_{2} \mathrm{SO}_{4}$ at $0.5 \mathrm{~N}$. The ethanol yield was 15 to $18 \mathrm{~g} / \mathrm{L}$ representing about 78 to $92 \%$ of the theoretical yield.
\end{abstract}

Keywords: Beta vulgaris L; pretreatment; Pirt; logistic; Luedeking-Piret

Received: 05/04/2021

Accepted: 31/08/2021

Available online: 31/12/2021.

* Research article.

a PhD in Biotechnology. Instituto Tecnológico Superior de Huichapan, Renewable Energy Engineering Division. Huichapan, Mexico. E-mail: djimenez@iteshu.edu.mx ORCID: http://orcid.org/0000-0001-8227-2525

b MS in Biotechnology. Instituto Tecnológico Superior de Huichapan, Renewable Energy Engineering Division. Huichapan, Mexico. E-mail: madox0666@yahoo.com.mx ORCID: http://orcid.org/0000-0003-2636-6177

c PhD in Chemistry. Instituto Tecnológico Superior de Huichapan, Renewable Energy Engineering Division. Huichapan, Mexico. E-mail: javenegas@iteshu.edu.mx ORCID: http://orcid.org/0000-0001-6220-6440

d $\quad \mathrm{PhD}$ in Biotechnology. Chemistry Department. Universidad Autónoma de Querétaro. Querétaro, Mexico. E-mail: gracidaj@netscape.net ORCID: http://orcid.org/0000-0001-9475-6594 
How to cite: D. Jiménez-Islas, J. M. Rivera-Ríos, J. A. Venegas Sánchez, and J. N. Gracida Rodríguez, “Hydrolysis of Red Beet Bagasse and Modeling of Hydrolysates for Bioethanol Production: Hydrolysis of Red Beet Bagasse and Modeling of Hydrolysates for bioethanol production", Cien.Ing.Neogranadina, vol. 31, no. 2, pp. 135-147, Dec. 2021.

\section{Hidrólisis del bagazo de remolacha roja y modelado de hidrolizados para la producción de bioetanol}

Resumen: la remolacha roja en México se utiliza en la industria de los colorantes, pero el jugo de su bagazo (BRR) puede ser un carbohidrato para la producción de etanol. El presente estudio tiene como objetivo el pretratamiento del brr con ácido $\left(\mathrm{H}_{2} \mathrm{SO}_{4}\right)$ y álcali $(\mathrm{NaOH})$ para mejorar la disponibilidad de azúcares. Además, se describe de forma cuantitativa en los hidrolizados el crecimiento microbiano, el consumo de sustrato y la producción de etanol con simulación mediante la cinética de datos de la remolacha roja y las ecuaciones logística, de Pirt y de Luedeking-Piret. Los experimentos con $\mathrm{H}_{2} \mathrm{SO}_{4}$ en condiciones de esterilización dieron como resultado una menor formación de fenoles y un aumento de la hidrólisis al $32 \%$. Se utilizaron las ecuaciones mencionadas para describir cuantitativamente los hidrolizados, el crecimiento microbiano, el consumo de sustrato y la producción de etanol, respectivamente. En el tratamiento con álcali, se encontró una diferencia media significativa $(p<0.05)$ en la masa del sustrato y el tiempo de reacción. El rendimiento máximo de $38 \mathrm{~g} / \mathrm{L}$ de azúcares totales a las $72 \mathrm{~h}$ de reacción se obtuvo a partir de $6 \mathrm{~g}$ de BRR y $\mathrm{H}_{2} \mathrm{SO}_{4}$ a $0,5 \mathrm{~N}$. El rendimiento de etanol fue de $15 \mathrm{~g} / \mathrm{L}$ a $18 \mathrm{~g} / \mathrm{L}$, lo que representa aproximadamente del $78 \%$ al $92 \%$ del rendimiento teórico.

Palabras clave: Beta vulgaris L; pretratamiento; Pirt; logística; Luedeking-Piret 


\section{Introduction}

Energy is considered a significant indicator of economic and social development for any nation [1]; the transport sector is the leading world's energy consumption, and it remains heavily reliant on fossil fuels, particularly petroleum-based liquid fuels [2]. In this context, the high energy demand, the depletion of fossil fuel reserves, and the increase of greenhouse gas emissions have led to the resurgence of alternative fuels such as biofuels. Nowadays, bioethanol and biodiesel have already been produced as alternatives [3]; bioethanol is usually made by fermenting the sugars in crops like wheat, corn (maize), sugar cane mash, or molasses, and in some more recent applications, switchgrass, or wood-derived biomass [4]. The bioethanol demand and production are increasing continuously, and it has a higher octane number, higher heat of evaporation than gasoline, and is predominantly considered renewable and environmentally friendly [5]. Additionally, ethanol from renewable sources can be used as an alternative fuel or an oxygenating additive to the current fossil fuels. The production of bioethanol from agricultural lignocellulosic waste can be sustainable and feasible.

Nevertheless, the availability of sugars for fermentation is low and needs pretreatment to fractionate and release fermentable sugars. The pretreatment of these materials changes the physical-chemical structure of the lignocellulosic biomass and improves the hydrolysis rate [6]. Several processes have been developed for the treatment of lignocelluloses, including hot water [7], steam explosion [8], ultrasound-assisted with acid treatment [9], alkali treatment [10], and enzymatic treatment [11]. These processes enhance the availability of sugars by increasing porosity and changing the crystallinity, which is critical in the subsequent bioconversion process to ethanol. However, the pretreatments of lignocellulosic materials are limited for the recalcitrance caused by high amounts of lignin. Pretreatments could be less expensive when substrates with low amounts of lignin such as Beta vulgaris monorosa, Beta vulgaris L. conditiva, and Beta vulgaris alttisima. In this sense, Mexico stands out with the red beet
(Beta vulgaris L. conditiva) available all the year; then, beet can be used with the juice and bagasse for bioethanol production. In Mexico, the abundance of red beet in the country's central regions allows us to investigate the idea of using color industry processing residues. Furthermore, it is possible to use beets that do not meet commercial quality standards as a bioenergetic crop in Mexico.

On the other hand, Beta vulgaris L. can be saccharified to increase the availability of sugars because it has low lignin content, making the pretreatment less severe and cost affordable. The sugar beet pulp was characterized and reported with (\%w/w): 30.55 cellulose, 25.92 hemicelluloses, 3.91 lignin [12]. Many pretreatment methods have been investigated for the hydrolysis of different Beta vulgaris or by-products of the industrially processed sugar beet. The ethanol production from sugar beet pulp hydrolysate is obtained by diluting acid pretreatment and Pichia stipitis yeast in Turkey [13]. Beet pulp was undergoing ammonia pressurization and hydrolyzed as described in the methodology [14]. Beta vulgaris cv. monorosa (fodder beet) was adjusted to $\mathrm{pH} 3$ (partial hydrolysis) to inhibit bacterial contamination and was fermented to ethanol [15]. Some authors reported the effect of the factors: reaction time, substrate concentration, temperature, and speed stirring on the hydrolysis of sugar beet [16], [17].

With the available sugars, it is necessary to develop models to describe ethanol production using microorganisms; the analysis of rate equations for microbial growth, substrate uptake, and product formation facilitates the prediction of experimental conditions [18], [19].

Information regarding the influence of time, uptake of sugars, and biomass growth is still necessary to understand and improve ethanol productivity; mathematical models are valuable tools for this purpose. Several structured and unstructured mathematical models have been developed which attempt to describe the fermentation reaction. Using logistics, Pirt, and Luedeking-Piret equations , we can describe the fermentation of juice and hydrolysates of red beet bagasse [20], [21].

The present study aims to pretreat red beet bagasse using acid and alkali to improve the 
availability of sugars and describe quantitatively in the hydrolysates the microbial growth, substrate consumption, and ethanol production with simulation using data kinetics of red beet and logistic, Pirt, and Luedeking-Piret equations.

\section{Materials and Methods}

Experiments were carried out with $\mathrm{H}_{2} \mathrm{SO}_{4}$ and $\mathrm{NaOH}$ (conditions described in Table 1) to examine the influence of alkali and acid hydrolysis on Beta vulgaris L. bagasse (R вв). In addition, R вB was hydrolyzed in conditions of sterilization.

Table 1. Matrix design of hydrolysis a) acid; b) alkaline.

\begin{tabular}{|c|c|c|c|c|c|c|c|}
\hline a) & & & & b) & & & \\
\hline Run & $\begin{array}{l}\mathrm{H}_{2} \mathrm{SO}_{4} \\
(\mathrm{~N})\end{array}$ & $\begin{array}{l}\text { Mass } \\
(\mathrm{g})\end{array}$ & $\begin{array}{l}\text { Time } \\
\text { (h) }\end{array}$ & Run & $\begin{array}{l}\mathrm{NaOH} \\
(\mathrm{N})\end{array}$ & $\begin{array}{l}\text { Mass } \\
(\mathrm{g})\end{array}$ & $\begin{array}{l}\text { Time } \\
\text { (h) }\end{array}$ \\
\hline 1 & 0.1 & 2 & 24 & 28 & 0.1 & 2 & 24 \\
\hline 2 & 0.1 & 2 & 48 & 29 & 0.1 & 2 & 48 \\
\hline 3 & 0.1 & 2 & 72 & 30 & 0.1 & 2 & 72 \\
\hline 4 & 0.1 & 4 & 24 & 31 & 0.1 & 4 & 24 \\
\hline 5 & 0.1 & 4 & 48 & 32 & 0.1 & 4 & 48 \\
\hline 6 & 0.1 & 4 & 72 & 33 & 0.1 & 4 & 72 \\
\hline 7 & 0.1 & 6 & 24 & 34 & 0.1 & 6 & 24 \\
\hline 8 & 0.1 & 6 & 48 & 35 & 0.1 & 6 & 48 \\
\hline 9 & 0.1 & 6 & 72 & 36 & 0.1 & 6 & 72 \\
\hline 10 & 0.3 & 2 & 24 & 37 & 0.3 & 2 & 24 \\
\hline 11 & 0.3 & 2 & 48 & 38 & 0.3 & 2 & 48 \\
\hline 12 & 0.3 & 2 & 72 & 39 & 0.3 & 2 & 72 \\
\hline 13 & 0.3 & 4 & 24 & 40 & 0.3 & 4 & 24 \\
\hline 14 & 0.3 & 4 & 48 & 41 & 0.3 & 4 & 48 \\
\hline 15 & 0.3 & 4 & 72 & 42 & 0.3 & 4 & 72 \\
\hline 16 & 0.3 & 6 & 24 & 43 & 0.3 & 6 & 24 \\
\hline 17 & 0.3 & 6 & 48 & 44 & 0.3 & 6 & 48 \\
\hline 18 & 0.3 & 6 & 72 & 45 & 0.3 & 6 & 72 \\
\hline 19 & 0.5 & 2 & 24 & 46 & 0.5 & 2 & 24 \\
\hline 20 & 0.5 & 2 & 48 & 47 & 0.5 & 2 & 48 \\
\hline 21 & 0.5 & 2 & 72 & 48 & 0.5 & 2 & 72 \\
\hline 22 & 0.5 & 4 & 24 & 49 & 0.5 & 4 & 24 \\
\hline
\end{tabular}




\begin{tabular}{cccccccc}
23 & 0.5 & 4 & 48 & $\mathbf{5 0}$ & 0.5 & 4 & 48 \\
\cline { 2 - 7 } 24 & 0.5 & 4 & 72 & $\mathbf{5 1}$ & 0.5 & 4 & 72 \\
\hline 25 & 0.5 & 6 & 24 & $\mathbf{5 2}$ & 0.5 & 6 & 24 \\
26 & 0.5 & 6 & 48 & $\mathbf{5 3}$ & 0.5 & 6 & 48 \\
27 & 0.5 & 6 & 72 & $\mathbf{5 4}$ & 0.5 & 6 & 72 \\
Source: Own elaboration & &
\end{tabular}

Red beet preparation. Samples of RBB were provided by a farmer from Hidalgo, Mexico, and kept frozen until used. RBв was washed and passed through an extractor hammermill (Moullinex A75312). The red beet was dried for $24 \mathrm{~h}$ at $70{ }^{\circ} \mathrm{C}$ and homogenized to quantify the mass concentration; then passed into a mill of 12-32 mesh size screens kept at $4{ }^{\circ} \mathrm{C}$.

Experimental design/alkaline treatment. Selected factors and their levels for the experimental designs are shown in Table 1a. The experimental design consisted of three levels of alkali concentration $(0.1,0.3$, and $0.5 \mathrm{~N})$, three levels of time $(24,48$, and $72 \mathrm{~h}$ ), and three levels of mass $(2,4$, and $6 \mathrm{~g}$ of dry RвB). The number of experiments was from run 1 to 27 of the matrix design (Table 1a). Experiments were carried out in 250 $\mathrm{mL}$ Erlenmeyer flasks, and each flask contained 50 $\mathrm{mL}$ of $\mathrm{NaOH}$ at different concentrations. All flasks were maintained at room temperature and static. Samples were collected filtered at regular intervals of time $(24,48$, and $72 \mathrm{~h})$.

Experimental design/acid treatment. Sulfuric acid was used for hydrolysis, and three different levels were applied, concentration (0.1, 0.3 , and 0.5 $\mathrm{N})$, pretreatment time $(24,48$, and $72 \mathrm{~h})$, and mass $(2,4$, and $6 \mathrm{~g}$ of dry RвB). The number of experiments was from run 28 to 54 of the matrix design (Table 1b). The acid hydrolysis of RвB was similar to that used in the alkali treatment but using $\mathrm{H}_{2} \mathrm{SO}_{4}$.

Hydrolysis at sterilization conditions. Different concentrations of $\mathrm{H}_{2} \mathrm{SO}_{4}(0,2,4,6$, and $8 \% \mathrm{v} / \mathrm{v})$ were applied to determine the best concentration for the release of sugars; the reaction was carried out at sterilization conditions $\left(11 \mathrm{~min}, 121{ }^{\circ} \mathrm{C}, 1\right.$ $\mathrm{kg} / \mathrm{cm}^{2}$ ). The experiments were conducted in 250
$\mathrm{mL}$ Erlenmeyer flasks. Six grams of dry RвB were placed in $50 \mathrm{~mL}$ of $\mathrm{H}_{2} \mathrm{SO}_{4}$ of different concentrations $(0,2,4,6$, and $8 \% \mathrm{v} / \mathrm{v})$, then were sterilized in an autoclave for 11 minutes at $121{ }^{\circ} \mathrm{C} / 1 \mathrm{~kg} /$ $\mathrm{cm}^{2}$, and kept overnight at $20^{\circ} \mathrm{C}$. Samples were filtered to determine total sugars with a modified phenol-sulfuric method and phenolic compounds [22]. The percent of hydrolysis was determined concerning the total sugars and the dry weight of red beet.

Analytical techniques. The moisture content of RBB was analyzed by heating a known weight at $70{ }^{\circ} \mathrm{C}$ for $24 \mathrm{~h}$. Total sugar content was determined by the phenol sulfuric acid method using glucose as standard [23]. Glucose standard samples were prepared to establish the calibration curve. The acid hydrolysate was analyzed through HPLC Agilent (RID with column Bio-Rad HPX$87 \mathrm{H}), \mathrm{H}_{2} \mathrm{SO}_{4} 0.0045 \mathrm{~N}$ was used as a mobile phase. The phenolic compounds were determined by the Folin-Ciocalteu method [24]. Tukey and Dunnet test for multiple comparisons were used to find meaningful differences, while multivariate and effects between-subject tests were performed for the effect of interaction between factors. The SPSS statistical package (version 17) was used for all the statistical applications.

Modeling. The logistic, Pirt and Luedeking-Piret equations can be used to obtain simpler ones to establish relationships between growth, substrate consumption, growth, and product synthesis. Eq. 1 is obtained by integration of the logistic equation, while eqs. 2 and 3 are obtained by dividing the Pirt, and Luedeking-Piret equations, respectively, by the logistic equation followed by integration, as demonstrated previously [20]: 


$$
\begin{array}{r}
X(t)=\frac{X_{\max }}{1+\left(\frac{X_{\max }}{X_{0}}-1\right) e^{-\mu_{\max } t}} X(t)=\frac{X_{\max }}{1+\left(\frac{X_{\max }}{X_{0}}-1\right) e^{-\mu_{\max } t}} \\
S(X)=S_{0}-\frac{1}{Y_{\frac{X}{S}}}\left(X-X_{0}\right)-\frac{m X_{\max }}{\mu_{\max }} \operatorname{Ln}\left(\frac{X_{\max }-X_{0}}{X_{\max }-X}\right) \\
P(X)=P_{i}+\alpha_{1}\left(X-X_{0}\right)-\frac{\beta_{i} X_{\max }}{\mu_{\max }} \operatorname{Ln}\left(\frac{X_{\max }-X_{0}}{X_{\max }-X}\right)
\end{array}
$$

\begin{tabular}{|c|c|}
\hline \multicolumn{2}{|c|}{ Nomenclature } \\
\hline$X$ & biomass concentration/(g/L) \\
\hline$X_{0}$ & biomass concentration at $t=0 /(\mathrm{g} / \mathrm{L})$ \\
\hline$t$ & time/h \\
\hline$X_{\max }$ & maximum biomass concentration/(g/L) \\
\hline$\mu$ & specific growth rate $/ \mathrm{h}^{-1}$ \\
\hline$m_{\max }$ & maximum specific growth rate $/ \mathrm{h}^{-1}$ \\
\hline$S$ & sugar concentration/(g/L) \\
\hline$S_{0}$ & sugar concentration at $t=0 /(\mathrm{g} / \mathrm{L})$ \\
\hline$Y_{x / s}$ & $\begin{array}{l}\text { biomass per sucrose yield/(g of } \\
\text { biomass per g of sugar) }\end{array}$ \\
\hline$Y p / s$ & $\begin{array}{l}\text { ethanol per sugar yield/(g } \\
\text { of ethanol per g of sugar) }\end{array}$ \\
\hline$m$ & $\begin{array}{l}\text { maintenance coefficient/(g } \\
\text { of sugar per } g \text { of biomass per } h)\end{array}$ \\
\hline$P$ & concentration of the product/(g/L) \\
\hline$P i$ & concentration of the product at $\mathrm{t}=0 /(\mathrm{g} / \mathrm{L})$ \\
\hline$\alpha$ & $\begin{array}{l}\text { growth-associated coefficient for the product } /(\mathrm{g} \\
\text { of ethanol per } \mathrm{g} \text { of biomass) }\end{array}$ \\
\hline$\beta$ & $\begin{array}{l}\text { non-growth-associated coefficient for the } \\
\text { product/(g of ethanol per g of biomass per h) }\end{array}$ \\
\hline$Q p$ & $\begin{array}{l}\text { volumetric ethanol productivity/(g } \\
\text { of ethanol per L per h) }\end{array}$ \\
\hline
\end{tabular}

The kinetic data of red beet juice fermentation is used to describe the sugar of hydrolysates using the Solver function of Microsoft Excel (Microsoft Corporation, Redmond, WA, USA); the simulation program was designed to achieve the minimal normalized error using the Solver function. Eqs. 1-3 were fitted to the experimental data to determine the kinetic parameters for microbial growth. The experimental data and those generated by the model were analyzed using regression curve fitting (Microsoft Excel) with statistical significance set at $p=0.05$. The kinetics data were obtained with Saccharomyces cerevisiae ATCC 9763 [24].
The kinetic data were used to simulate the fermentation of hydrolysates.

\section{Results and Discussion}

Effect of alkaline treatment. For alkali treatment, the release of sugars was increased with the increasing mass of ввв. During the alkali hydrolysis, two phases were formed, a solid phase and a gelatinous solution with characteristics like pectin. The pectin of sugars beet hydrolyzed by a simple alkali process can form gels [25]. The maximum concentration of total sugars was observed at 24 hours, $28 \mathrm{~g} / \mathrm{L}$, from $6 \mathrm{~g}$ of dry mass (RBB) at a concentration of $0.3 \mathrm{~N} \mathrm{NaOH}$; at a concentration of $\mathrm{NaOH}$ of $0.5 \mathrm{~N}$ were obtained $24.5 \mathrm{~g} / \mathrm{L}$ (Fig. 1a). Multiple comparison tests (Tukey HSD) showed no significant $(p<0.05)$ differences between the different concentrations of $\mathrm{NaOH}$. The evaluation of interactions between the concentration of $\mathrm{NaOH}$ and the mass of Rвв on the total sugar release was analyzed by testing between-subjects effects. The analysis showed significant $(p<0.05)$ differences in the mass substrate due to the release of sugars at $24 \mathrm{~h}$ and the increase of substrate in the experiments. The $\mathrm{NaOH}$-mass concentration showed no significant $(p<0.05)$ differences in the release of the total sugars. This behavior suggests that in alkali pretreatment, the first reactions are solvation and saponification; this causes a swollen state of the biomass and makes it more accessible. In the reactions carried out with high alkali concentrations, the degradation and decomposition of dissolved polysaccharides occurred [26].

At 48 hours of reaction, the hydrolysis value was similar to that at 24 hours; hence there is no time effect on hydrolysis of bagasse (Fig. 1b). Usually, a significant fraction of the lignin is solubilized together with some of the hemicelluloses. A large fraction of the hemicellulose's sugars is usually recovered as oligomers. Alkaline pretreatment breaks the bonds between lignin carbohydrates and disrupts the lignin structure, making the carbohydrates more accessible [27]. The lignin content on sugar beet is less than $3 \%$ [28]; the conditions for the release of sugar with alkali were reduced 
by the scarce surface internal (porosity available) due to the low lignin content in the RвB. For this reason, the reaction of $\mathrm{NaOH}$ was reduced to the surface area of $\mathrm{RBB}$ and not at the internal area inside of the porous matrix that is generated in other substrates with higher lignin content [29].

Fig. 1c shows the alkaline hydrolysis of RBB at 72 hours. The maximum concentration of total sugars was $32 \mathrm{~g} / \mathrm{L}$ from $6 \mathrm{~g}$ of mass dry at a concentration of $0.5 \mathrm{~N}$ alkali. The interaction between the mass and alkali concentration was determined by test between subjects; the test shows that at 72 hours of reaction, the hydrolysis was significantly increased $(5 \mathrm{~g} / \mathrm{L})$ than at $24 \mathrm{~h}$. The increase of internal surface identifies the phenomenon that occurs with alkaline treatment on biomass, swelling, a decrease of polymerization degree and crystallinity, destruction of links between lignin and other polymers, and breakdown of lignin. The contact between the alkaline medium the ввв was the factor for the sugar increase from 27 to $32 \mathrm{~g} / \mathrm{L}$ at 48 and 72 hours, respectively. However, the $32 \mathrm{~g} / \mathrm{L}$ generated from bagasse can be used for ethanol production because they are cheap and renewable sources.
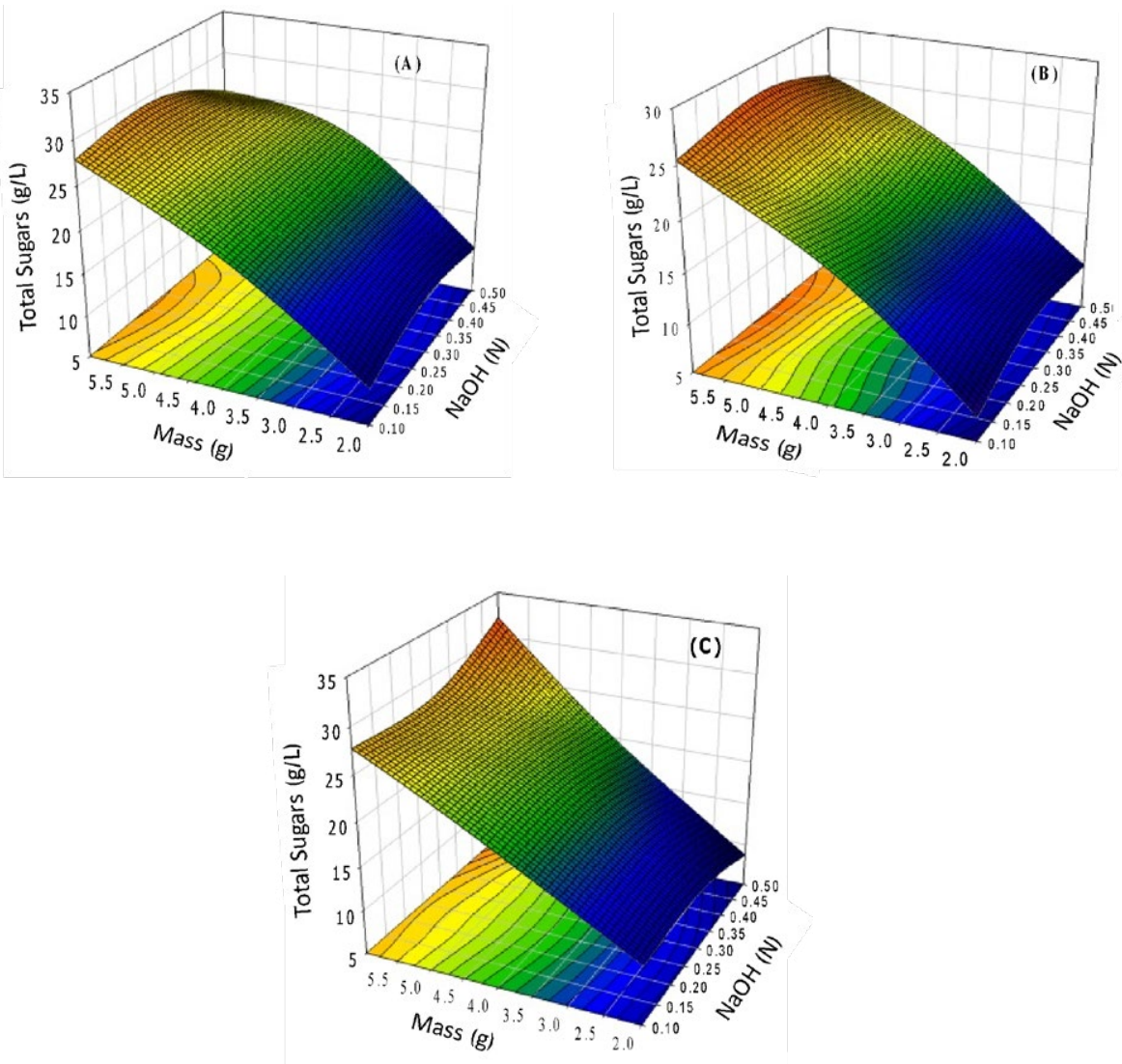

Fig. 1. Alkaline treatment, the effect of mass, and NaOH concentration on RBB: a) $24 \mathrm{~h}$, b) $48 \mathrm{~h}$, and c) $72 \mathrm{~h}$. The experiment was conducted at room temperature and without a stir. The experiment provides data of maximum total sugars at different times of reaction.

Source: Own elaboration 
Effect of acid treatment. The production of total sugars during the acid treatment is presented in Fig. 2. The release of sugars increased with the increase of acid concentration until $0.5 \mathrm{~N}$. The maximum concentration of total sugars was $27 \mathrm{~g} / \mathrm{L}$ which corresponds to $24 \mathrm{~h}$ of reaction, $6 \mathrm{~g}$ of dry mass, and $0.5 \mathrm{~N}$ acid concentration (Fig. 2a). The test of multiple comparisons (Tukey HSD) showed no significant $(p<0.05)$ differences between concentrations of acid from 0.1 to $0.3 \mathrm{~N}$. This may be due to the short time of contact between the substrate and the acid in all the preparations. For the concentration $0.5 \mathrm{~N}$, the test shows significant differences, which can be due to the effect of time and higher acid concentration.

For the effect of substrate, the ANOVA indicated significant positive differences in the release of sugar at $24 \mathrm{~h}$. In the evaluation of interactions of both factors (concentration of acid and mass of Rвв) on the hydrolysis, the between-subjects effects test was used; this analysis shows a significant $(p<0.05)$ difference of substrate on results of the released sugars at $24 \mathrm{~h}$. This later analysis must be taken as a reference to consider in interactions between factors. The interaction between mass and acid concentration favored hydrolysis by increasing the contact area of the particles of RBB; the external surface increased with the addition of mass.

Fig. $2 b$ shows the effect of the RBB mass and acid concentration on hydrolysis after 48 hours.
The maximum concentration of total sugars was $35 \mathrm{~g} / \mathrm{L}, 30 \%$ higher than that obtained at 24 hours of reaction. At 48 hours, the hydrolysis reaction was significantly increased from 4 and $6 \mathrm{~g}$ of mass.

With increasing mass (from 4 to $6 \mathrm{~g}$ ) and reaction time (from 24 to 48 hours), the hydrolysis is incremented by the attack of acid on both surface area of $\mathrm{RBB}$ and matrix porous generated during hydrolysis. Some reports suggested that the matrix of lignocellulose should be broken heterogeneous to reduce the cellulose's crystallinity degree [29]; also, the hydrolysis reaction is a heterogeneous reaction that affects all the porous matrix, and structure changes as a function of time.

Fig. $2 \mathrm{c}$ presents the hydrolysis profiles of $\mathrm{RBB}$ at 72 hours. The concentration of total sugars was 38 $\mathrm{g} / \mathrm{L}$. The interaction between mass and acid concentration shows the interaction of factors. In 72 hours of reaction, the hydrolysis was significantly increased, $8.5 \%$ higher than that obtained at 48 hours. With the multivariate test (Wilk's Lambda), the concentration of acid and mass of rbb have significant effects. Also, the increase in reaction time affected the hydrolysis due to the dissemination of acid to the matrix internally and the increased surface porous, which is consistent with the result obtained in this work, where the particle size was reduced and the effect of the mechanical treatment, together with the factor evaluated, favors the release of total sugars.
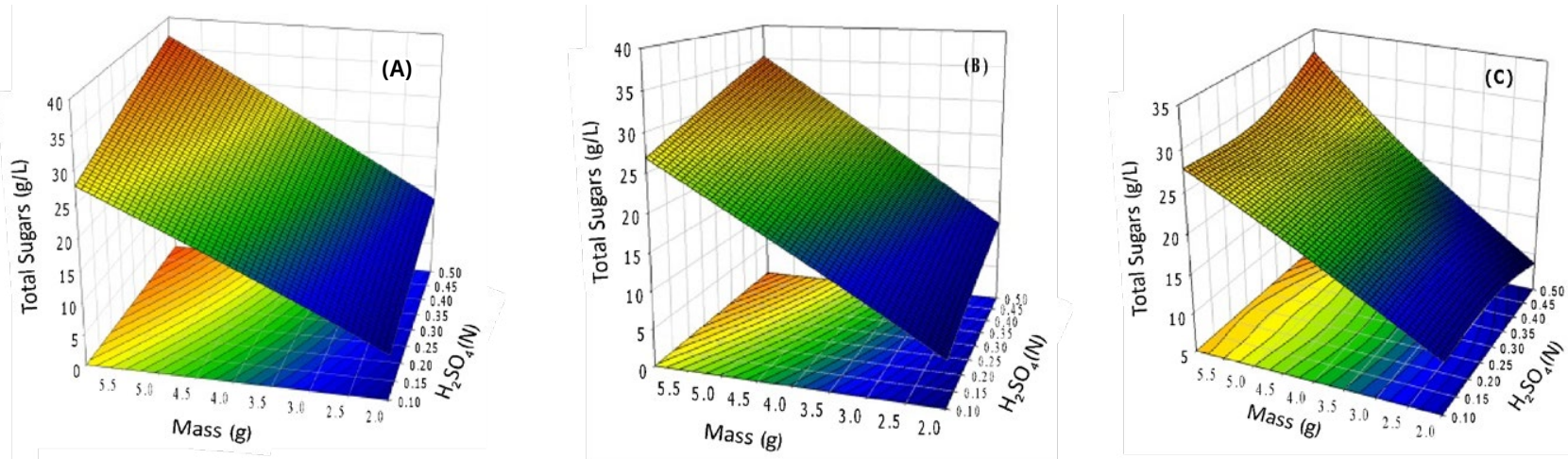

Fig. 2. Acid treatment, the effect of mass, and acid concentration on RBB: a) $24 \mathrm{~h}$, b) $48 \mathrm{~h}$ and c) $72 \mathrm{~h}$. The experiment was conducted at room temperature and without a stir. The experiment provides data of maximum total sugars at different times of reaction.

Source: Own elaboration 
Hydrolysis using dilute acid (0.1-0.3 N) at 24 $\mathrm{h}$ was slow $(8 \mathrm{~g} / \mathrm{L})$; however, increasing acid concentration and the reaction time, the concentration of total sugars released was $37 \mathrm{~g} / \mathrm{L}$. So, the effect of acid pretreatment was more evident with the increase of time $(72 \mathrm{~h})$. To date, there are no reports on the hydrolysis of Beta vulgaris L; but, using sugar cane bagasse [30], the optimal conditions obtained were $0.5 \%$ of $\mathrm{H}_{2} \mathrm{SO}_{4}, 121{ }^{\circ} \mathrm{C}, 1 \mathrm{~kg} /$ $\mathrm{cm}^{2}$ in an autoclave; yielding the concentration of a total sugar of $24.7 \mathrm{~g} / \mathrm{L}$. The reaction time range was 15-240 min, but the energy used in the hydrolysis conditions was higher than this work. The best condition of hydrolysis of RBB was obtained with acid treatment. While in alkali treatment, the solubility of pectin provoked separate phases (gelatinous and solid) on the reaction medium; this is detrimental to the total sugar release due to the decreasing the interaction between catalyst and the substrate. HPLC analysis of carbohydrates from hydrolysates shows the main composition of glucose $20.9 \%$ and fructose $68.1 \%$; meanwhile, sucrose was not found. Hence, products of RBв like glucose and fructose can be fermented by yeasts, for example, Saccharomyces cerevisiae, strains that can ferment glucose, and fructose without inhibition by the substrate.

Hydrolysis at sterilization conditions. Hydrolysis of RBB in extreme conditions (autoclave) was 12 and $32 \%$ in control (without acid) and with acid, respectively. The test of Dunnet indicated significant $(p<0.05)$ differences between the control and the treatments. With $2-8 \%$ of acid, the hydrolysis conditions show no significant differences. At $2 \%$, the medium can be used for hydrolysis of RBB with autoclave conditions at 11 minutes (Fig. 3). Under high temperature and pressure conditions, hydrolysis processes generate by-products that are inhibitors compounds for the microorganism in the fermentation of sugars.

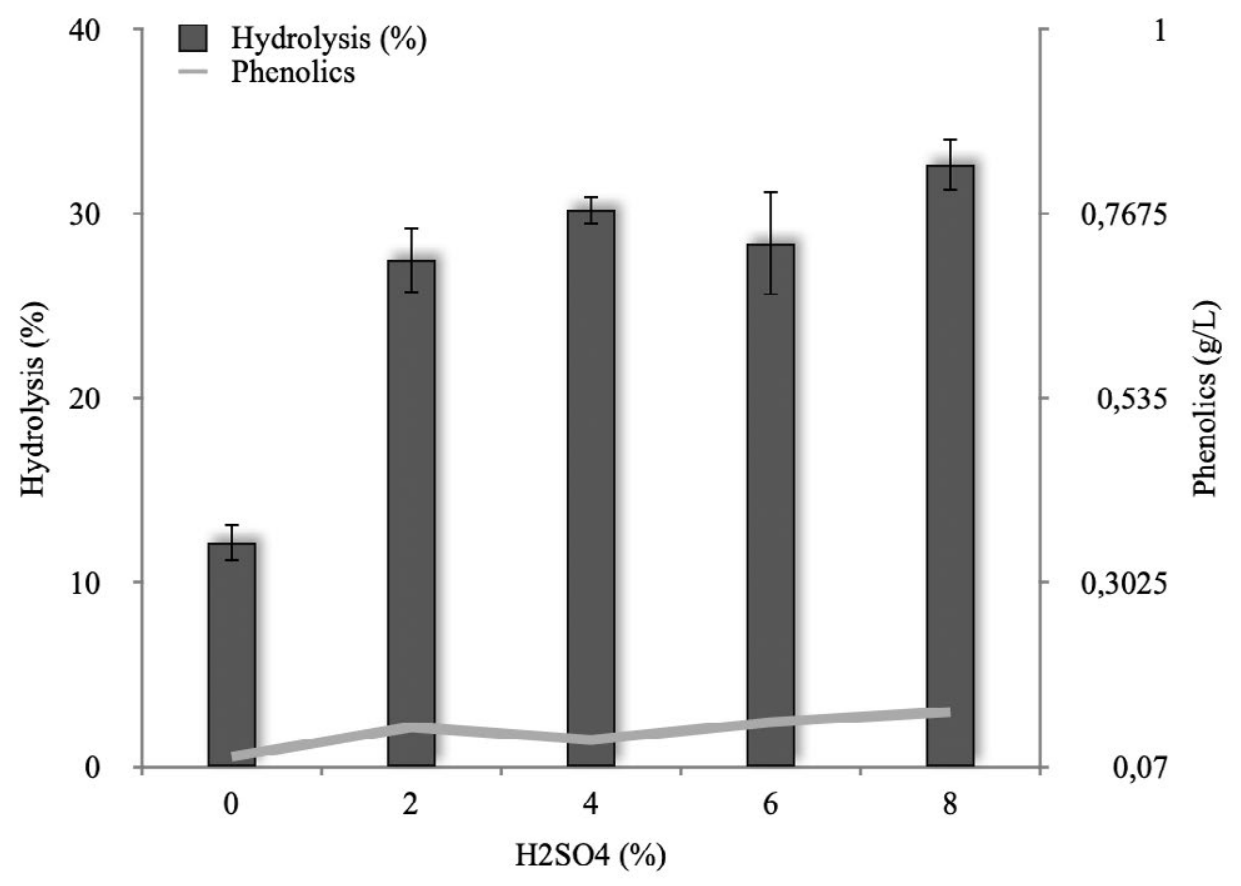

Fig. 3. Hydrolysis of RBB at sterilization conditions. Continuous line phenolics compound. Source: Own elaboration 
The total concentration of sugars released in the process of hydrolysis, and the own juices of the red beet, are sugars available to improve the process fermentatively. The salts formed during neutralization can be used in the culture media for the fermentation to ethanol. Harnessing autoclave conditions, time reaction extension, and acid catalysts can generate the best conditions for the pretreatment and reduce energy uptake.

Modeling. The profile of ethanol production, growth of biomass, and sugar consumption are obtained with the simulation of hydrolysates acid and alkaline red beet juice by $S$. cerevisiae ATCC 9763, Figs. 4 and 5, respectively. The ethanol production by $S$. cerevisiae ATCC 9763 was obtained between 16 and $24 \mathrm{~h}$; the production of ethanol estimate by the model was 15 to $18 \mathrm{~g} / \mathrm{L}$ with hydrolysates of acid treatment; however, the theoretical yield was 78 to $92 \%$ by Saccharomyces cerevisiae. At an experimental and industrial level, only between $87-95$ of the theoretical yield of ethanol is reached in the fermentation [31].
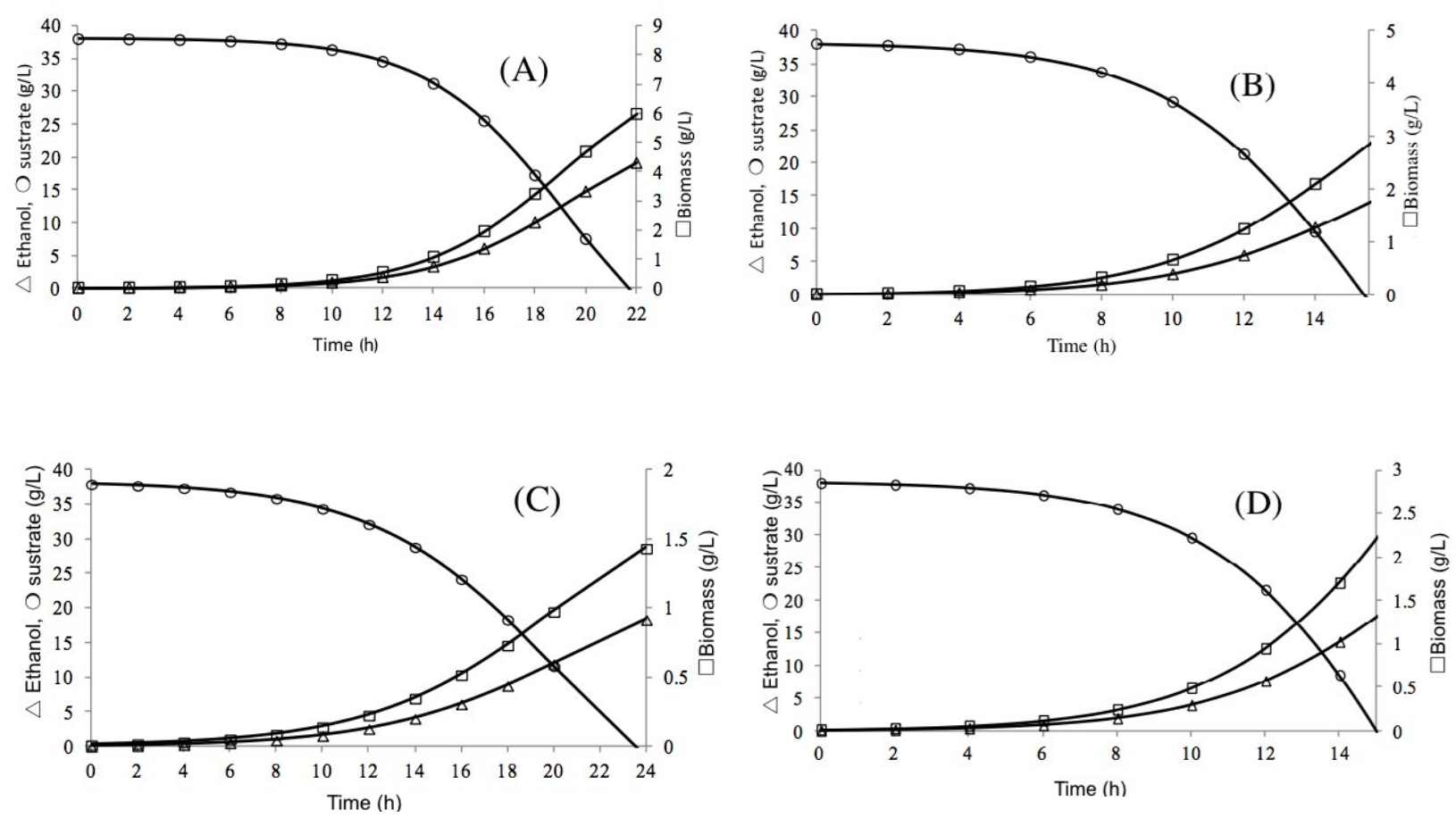

Fig. 4. Fermentation of hydrolysates acid of Beta vulgaris L. Ethanol production, sugar consumption, and growth of Saccharomyces cerevisiae ATCC 9763. $\mathrm{pH} 2.8$ and $30^{\circ} \mathrm{C}(\mathrm{A}) ; \mathrm{pH} 5.5$ and $30^{\circ} \mathrm{C}(\mathrm{B}) ; \mathrm{pH} 2.8$ and $37^{\circ} \mathrm{C}(\mathrm{C})$, and; $\mathrm{pH} 5.5$ and $37^{\circ} \mathrm{C}(\mathrm{D})$.

Source: Own elaboration 

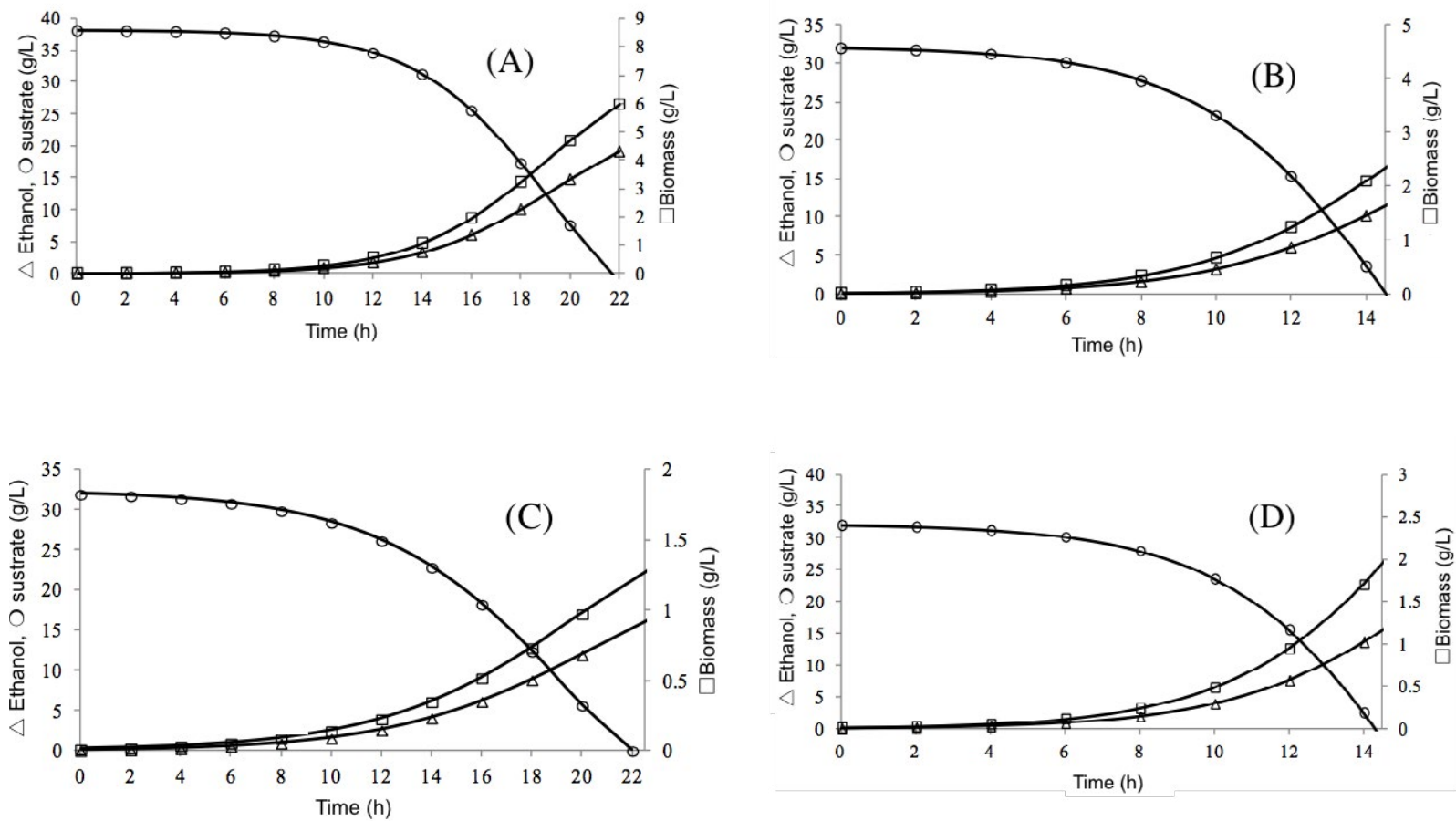

Fig. 5. Fermentation of hydrolysates alkaline of Beta vulgaris $\mathrm{L}$. Ethanol production, sugar consumption, and growth of Saccharomyces cerevisiae ATcC 9763. $\mathrm{pH} 2.8$ ans $30^{\circ} \mathrm{C}(\mathrm{A}) ; \mathrm{pH} 5.5$ and $30^{\circ} \mathrm{C}(\mathrm{B}) ; \mathrm{pH} 2.8$ and $37^{\circ} \mathrm{C}(\mathrm{C})$, and; $\mathrm{pH} 5.5 \mathrm{y}$ $37^{\circ} \mathrm{C}(\mathrm{D})$.

Source: Own elaboration

The ethanol production by $S$. cerevisiae ATCC 9763 was obtained between 14 and $22 \mathrm{~h}$, the production of ethanol estimate by the model was 12 to $15.5 \mathrm{~g} / \mathrm{L}$ with hydrolysates of alkaline treatment, the variability of these results can be explained by the initial concentration of sugar, due to theoretical yield were 73 to $94 \%$, both yields are similar.

These simulations of hydrolysates show that the production of ethanol is growth-associated at different conditions of fermentation. The biomass, product, and substrate profiles by $S$. cerevisiae ATCC 9763 were similar. It is essential to point out that this mathematical model could predict the fermentation under simulation using fermentation data kinetics of red beet juice. A mathematical model is a tool, and the fitted values of its parameters are valid for the conditions used in this study.

\section{Conclusion}

From the data, the reaction time mass of $\mathrm{RBB}$ in the reaction medium is a critical factor in the hydrolysis process; the acid pretreatment also vital achieves better yields than the alkaline pretreatment. The concentration of $\mathrm{NaOH}$ had a more negligible effect on the hydrolysis, and the mass of RBB and the reaction time are factors to obtain significant hydrolysis of RBв. The equations used to simulate the fermentation of hydrolysates could estimate 
the yield of ethanol, uptake of sugar, and growth of biomass under different conditions.

\section{References}

[1] K. Baz, J. Cheng, D. Xu, K. Abbas, I. Ali, H. Ali, and C. Fang, "Asymmetric impact of fossil fuel, and renewable energy consumption on economic growth: A nonlinear technique," Energy, vol. 226, p. 120357, Jul. 2021, DoI: https://doi.org/10.1016/j.energy.2021.120357

[2] M. Ebadian, S. van Dyk, J. D. McMillan, and J. Saddler, "Biofuels policies that have encouraged their production, and use: An international perspective," Energy Policy, vol. 147, p. 111906, Dec. 2020, DoI: https://doi.org/10.1016/j.enpol.2020.111906

[3] Z. Liu, H. Moradi, S. Shi, and F. Darvishi, "Yeasts as microbial cell factories for sustainable production of biofuels," Renew. Sust. Energ. Rev., vol. 143, p. 110907, Jun. 2021, DOI: https://doi.org/10.1016/j. rser.2021.110907

[4] M. R. Barr, R. Volpe, and R. Kandiyoti, "Liquid biofuels from food crops in transportation - A balance sheet of outcomes," Chem. Eng. Sci., vol. 10, p. 100090, May 2021, DOI: https://doi.org/10.1016/j. cesx.2021.100090

[5] H. Yuan, L. Tan, K. Kida, S. Morimura, Z.-Y. Sun, and Y.-Q. Tang, "Potential for reduced water consumption in biorefining of lignocellulosic biomass to bioethanol, and biogas," J. Biosci. Bioeng., Jan. 2021, Dor: https://doi.org/10.1016/j.jbiosc.2020.12.015

[6] P. Kumar, D. M. Barrett, M. J. Delwiche, and P. Stroeve, "Methods for pretreatment of lignocellulosic biomass for efficient hydrolysis, and biofuel production," Ind. Eng. Chem. Res., vol. 48, no. 8, pp. 3713-3729, Apr. 2009, Dor: https://doi.org/10.1021/ie801542g

[7] H. K. Sreenath, R. G. Koegel, A. B. Moldes, T. W. Jeffries, and R. J. Straub, "Ethanol production from alfalfa fiber fractions by saccharification, and fermentation," Process Biochem., vol. 36, no. 12, pp. 1199-1204, Jun. 2001, DoI: https://doi.org/10.1016/ s0032-9592(01)00162-5

[8] F. Pereira Marques, A. K. Lima Soares, D. Lomonaco, L. M. Alexandre e Silva, S. Tédde Santaella, M. de Freitas Rosa, and R. Carrhá Leitão, "Steam explosion pretreatment improves acetic acid organosolv delignification of oil palm mesocarp fibers, and sugarcane bagasse," Int. J. Biol. Macromol., vol. 175, pp. 304-312, Apr. 2021, DoI: https://doi.org/10.1016/j. ijbiomac.2021.01.174

[9] S. Paramasivan, S. Sankar, R. Senthil Velavan, T. Krishnakumar, R. S. I. Batcha, and K. S. Muthuvelu, "Assessing the potential of lignocellulosic energy crops as an alternative resource for bioethanol production using ultrasound assisted dilute acid pretreatment," Mater. Today: Proc., Feb. 2021, DoI: https://doi. org/10.1016/j.matpr.2020.12.470

[10] A. Bartos, J. Anggono, Á. E. Farkas, D. Kun, F. E. Soetaredjo, J. Móczó, Antoni, H. Purwaningsih, and B. Pukánszky, "Alkali treatment of lignocellulosic fibers extracted from sugarcane bagasse: Composition, structure, properties," Polym. Test., vol. 88, p. 106549, Aug. 2020, Dor: https://doi.org/10.1016/j.polymertesting.2020.106549

[11] Y. Sheng, S. S. Lam, Y. Wu, S. Ge, J. Wu, L. Cai, Z. Huang, Q. V. Le, C. Sonne, and C. Xia, "Enzymatic conversion of pretreated lignocellulosic biomass: A review on influence of structural changes of lignin," Bioresour. Technol., vol. 324, p. 124631, Mar. 2021, DOI: https://doi.org/10.1016/j.biortech.2020.124631

[12] H. Şenol, Ü. Açıkel, S. Demir, and V. Oda, "Anaerobic digestion of cattle manure, corn silage, and sugar beet pulp mixtures after thermal pretreatment, and kinetic modeling study," Fuel, vol. 263, p. 116651, Mar. 2020, DOI: https://doi.org/10.1016/j.fuel.2019.116651

[13] H. Günan Yücel, and Z. Aksu, "Ethanol fermentation characteristics of Pichia stipitis yeast from sugar beet pulp hydrolysate: Use of new detoxification methods," Fuel, vol. 158, pp. 793-799, Oct. 2015, Dor: https://doi. org/10.1016/j.fuel.2015.06.016

[14] B. Foster, B. Dale, and J. Doran-Peterson, J. "Enzymatic hydrolysis of sugar beet pulp," Appl. Biochem. Biotechnol., 2001, vol. 91-93, pp. 1-9, DoI: https://doi. org/10.1385/abab:91-93:1-9:269.

[15] W. Gibbons, and C. Westby, "Effects of inoculum size on solid-phase fermentation of fodder beets for fuel ethanol production," Appl. Environ. Microbiol., vol. 52, pp 960-962. Oct. 1986.

[16] Y. Zheng, C. Lee, C. Yu, Y.-S. Cheng, R. Zhang, B. M. Jenkins, and J. S. VanderGheynst, "Dilute acid pretreatment, and fermentation of sugar beet pulp to ethanol," Appl. Energy, vol. 105, pp. 1-7, May 2013, DoI: https://doi.org/10.1016/j.apenergy.2012.11.070

[17] R. Chamy, A. Illanes, G. Aroca, and L. Nuñez, "Acid hydrolysis of sugar beet pulp as pretreatment for fermentation," Bioresour. Technol., vol. 50, no. 2, pp. 
149-152, Jan. 1994, DoI: https://doi.org/10.1016/09608524(94)90067-1

[18] R. Mitra and D. Duta, "Growth profiling, kinetics, and substrate utilization of low-cost dairy waste for production of $\beta$-cryptoxanthin by Kocuriamarina DAGII," Royal Soc. Open Sci., vol. 5, pp 1-19, 2018, DoI: https://doi.org/10.1098/rsos.172318

[19] N. Phukoetphim, A. Salakkam, P. Laopaiboon, and L. Laopaiboon, "Kinetic models for batch ethanol production from sweet sorghum juice under normal, and high gravity fermentations: Logistic, and modified Gompertz models," J. Biotechnol., vol. 243, pp. 69-75, Feb. 2017, DoI: https://doi.org/10.1016/j.jbiotec.2016.12.012

[20] O. Soto-Cruz, E. Favela-Torres, and G. Saucedo-Castaneda, "Modeling of Growth, Lactate Consumption, and Volatile Fatty Acid Production by Megasphaera elsdenii Cultivated in Minimal, and Complex Media," Biotechnol. Prog., vol. 18, no. 2, pp. 193-200, Apr. 2002, DOI: https://doi.org/10.1021/bp010189y

[21] M. Germec, I. Turhan, M. Karhan, and A. Demirci, "Kinetic modeling, and techno-economic feasibility of ethanol production from carob extract based medium in biofilm reactor," Appl. Sci., vol. 9, no. 10, p. 2121, May 2019, DoI: https://doi.org/10.3390/app9102121

[22] F. Hanaa, "Assessment of freeze-dried hydrodistilled extracts from clove; caraway, and coriander herbs as natural preservatives for butter oil," Int. J. Dairy Sci., vol 4, pp. 67-73, 2009, DoI: https://doi.org/10.3923/ ijds.2009.67.73

[23] D. Jiménez, J. Páez, O. Soto, and J. Gracida, “Modelling of ethanol production from red beet juice by Saccharomyces cerevisiae under thermal, and acid stress conditions," Food Technol. Biotechnol., vol 52, pp. 93-100.

[24] H. F. M. Ali, “Assessment of Freeze-Dried Hydrodistilled Extracts from Clove; Caraway, and Coriander Herbs as Natural Preservatives for Butter Oil," Int. J. Dairy Sci., vol. 4, no. 2, pp. 67-73, Mar. 2009, Dor: https://doi.org/10.3923/ijds.2009.67.73

[25] P. Harel, G. de La Quérière, L. Mignot, and G.-A. Junter, "Mechanical properties of sugar beet Ca-pectate gel usable for cell immobilisation, and heavy metal accumulation," Ind. Crops Prod., vol. 11, no. 2-3, pp. 259-264, Mar. 2000, DoI: https://doi.org/10.1016/ s0926-6690(99)00054-0

[26] A. T. W. M. Hendriks, and G. Zeeman, "Pretreatments to enhance the digestibility of lignocellu- losic biomass," Bioresour. Technol., vol. 100, no. 1, pp. 10-18, Jan. 2009, DoI: https://doi.org/10.1016/j. biortech.2008.05.027

[27] M. Galbe and G. Zacchi, "Pretreatment of lignocellulosic materials for efficient bioethanol production," Adv. Biochem. Eng./Biotechnol., pp. 41-65, 2007, DOI: https://doi.org/10.1007/10_2007_070

[28] I. E. J. Milder, I. C. W. Arts, B. van de Putte, D. P. Venema, and P. C. H. Hollman, "Lignan contents of Dutch plant foods: a database including lariciresinol, pinoresinol, secoisolariciresinol, and matairesinol," Br. J. Nutr., vol. 93, no. 3, pp. 393-402, Mar. 2005, DoI: https://doi.org/10.1079/bjn20051371

[29] K. C. Nlewem and M. E. Thrash Jr., "Comparison of different pretreatment methods based on residual lignin effect on the enzymatic hydrolysis of switchgrass," Bioresour. Technol., vol. 101, no. 14, pp. 5426-5430, Jul. 2010, DoI: https://doi.org/10.1016/j. biortech.2010.02.031

[30] S. Pattra, S. Sangyoka, M. Boonmee, and A. Reungsang, "Bio-hydrogen production from the fermentation of sugarcane bagasse hydrolysate by Clostridium butyricum," Int. J. Hydrog. Energy, vol. 33, no. 19, pp. 5256-5265, Oct. 2008, DOI: https://doi.org/10.1016/j. ijhydene.2008.05.008

[31] C. Diaz, Y. Sierra, and J. Hernández, "Determination of the percentage of ethanol produced by Saccharomyces cerevisiae from semi-purified glycerin," J. Phys. Conf. Ser., 1126, 2008. 